\title{
Influence of Confounding Evidence Based Risk Factors Trig- gering the Incidence of HIV Antibodies among Screened Population of Niger Delta Extraction
}

Azuonwu Obioma ${ }^{1 *}$ and Azuonwu Testimonies Chikanka ${ }^{2}$

${ }^{1}$ Department of Medical Laboratory Science, Rivers State University of Science and Technology, Nigeria

${ }^{2}$ Department of Medical Microbiology, River State University of Port Harcourt, Nigeria

\begin{abstract}
The Human Immunodeficiency Virus (HIV) is transmittable through body fluids such as blood, breast milk and semen. Determination of its prevalence and associated risk factors are important especially in rural areas where the dwellers pay little or no concern to their health. This study was carried out in seven locations in Ahoada East Local Government Area of Rivers State, thus 1000 subjects were purposively recruited and screened for HIV1 and HIV1 and 2 respectively. The total prevalence was $10.7 \%$ out of which location 7 (Ahoada General Hospital) made up 3\% of the total prevalence. 2.9\% had dual infection by HIV and 2 while $7.8 \%$ had only HIV1. Females made up 52.6\% of HIV1 infections and $58.6 \%$ of HIV1 and 2 infections. Furthermore, subjects within ages 45 to 54 years had the prevalence of HIV1 and 2 (51.7\%) while subjects within ages 25-34 had the prevalence of HIV1 alone with them making up 44.9\% of the total prevalence. Based on profession, farmers made up $62.1 \%$ of the total HIV1 and 2 prevalence while students and farmers each made up $42.3 \%$ of the total HIV1 prevalence. Singles made up $67.9 \%$ of the total HIV1 prevalence while married persons made up $55.2 \%$ of the total prevalence. Education may have played a huge role in the prevalence of both HIV1 and HIV1 and 2 as there was none with either HIV 1 or 2 among those with a Master of Science degree while those with a Bachelor of Science made up only $7.6 \%$ of the total prevalence. Those with the Senior Secondary School Certificate recorded the highest percentage of the total prevalence for those who were HIV1 and 2 positive (44.8\%) while those with HIV1 made up 38.5\% of those who were HIV1 positive. All the HIV1 and 2 seropositive individuals admitted to being aware that condoms could help prevent the spread of the virus while $7.7 \%$ of those who were HIV1 positive said they were not aware that condoms could help in reducing the spread of the HIV infection. Awareness and continuous surveillance is key to reducing the spread of the HIV among the public and as such, should be carried out as often as possible especially in rural areas where little or no concern is paid to both individual and public health issues.
\end{abstract}

\section{Introduction}

The Human Immunodeficiency Virus is a RNA retrovirus whose long term infection leads to AIDS (Acquired Immune Deficiency Syndrome). In Nigeria, two cases of AIDS resulting from HIV was first diagnosed in 1985 but reported in 1986; A female sex worker was among the two cases [1]. When it first emerged, it was perceived by some as "American Idea for Discouraging Sex" [2]. In recent times, surveillance on HIV prevalence has become eminent since epidemiological data available shows that $\mathrm{HIV}$ is still a public health concern which has led to the loss of about 25 million lives within the past 30 years [3]. Sub-Saharan Africa accounted for about $67.6 \%$ of the worldwide HIV prevalence in 2009 while 25.8 million persons were estimated to be living with HIV in the same region as at the end of 2014 [4]. Of these, $9 \%$ are based in
Nigeria [5]. South Africa with 3 million infected persons ranks first in the continent with Nigeria being second in HIV prevalence in Africa [6].

Nevertheless, in 2005, its prevalence among women,

*Corresponding author: Dr. Azuonwu Obioma, Department of Medical Laboratory Science, Rivers State University of Science and Technology Nkpolu Oroworukwo, Port Harcourt, Nigeria, Tel: 234-803551968, E-mail: bimajacobs@ yahoo.co.uk

Received: March 13, 2018; Accepted: June 06, 2018; Published online: June 08, 2018

Citation: Obioma A, Chikanka AT (2018) Influence of Confounding Evidence Based Risk Factors Triggering the Incidence of HIV Antibodies among Screened Population of Niger Delta Extraction. Insights Biomed Res 2(1):32-39

Copyright: (c) 2018 Obioma A, et al. This is an open-access article distributed under the terms of the Creative Commons Attribution License, which permits unrestricted use, distribution, and reproduction in any medium, provided the original author and source are credited. 
Citation: Obioma A, Chikanka AT (2018) Influence of Confounding Evidence Based Risk Factors Triggering the Incidence of HIV Antibodies among Screened Population of Niger Delta Extraction. Insights Biomed Res 2(1):32-39

youths and children was $4.4 \%$ in Nigeria while in 2012 , the prevalence of HIV/AIDS in Nigeria was recorded to be between 4.1 and $6.0 \%$. In 2014, a total number of 220,000 new cases were reported. Previous studies have however shown that most children who were infected with the virus got it from their mothers from birth [7]. Regardless of the presence of antiretroviral therapy, Nigeria with a 3.2 million infected persons has been tagged second among nations with the HIV infection after South Africa which has an estimated 6.8 million infected persons $[5,6]$. Furthermore, practices such as female genital mutilation, multiple sex partners, traditional birth marks, tattooing and child delivery by unskilled traditional birth attendants are some of the confounding risk factors and practices that have led to increased HIV prevalence in Nigeria [8]. Having multiple sex partners has however, be found to be a major means of transmission of the virus as it accounts for $80 \%$ of cases; Same sex intercourse and intravenous drug use are however beginning to be of public health concern globally [9]. As well known, AIDS resulting from HIV has no cure; However, with the help of antiretroviral drugs and the patient keeping away from critical risk factors, it can be managed to large extent [10].

Although there is increased awareness on HIV/AIDS, only about $28 \%$ and $20 \%$ of men and women respectively say they can buy vegetables from an individual who is living with AIDS [11]. This is probably because most persons believe HIV/AIDS can be acquired though the consumption of food items from an infected person and while some strongly belief that since HIV/AIDS is transmitted through blood, thus, the food vendor may introduce his/her blood into the food and as such, may infect others. However, this trend with respect to belief and perceptions of community members about the partway of HIV infection tend to promote the issues of stigmatization among people living with HIV, and also preclude people for freely accessing the voluntary free testing and counseling services so as to avoid being stigmatized. As Awofala and Ogundele [12] who noted that, there is a good number of persons living with the HIV yet the recorded prevalence is low. It is therefore important that regular studies be carried out by relevant agencies on the prevalence of HIV in communities and states in $\mathrm{Ni}$ ger Delta, as this will help in knowing how far the fight against the virus has gone especially in our remote villages. It is for this reason that this study was carried out to determine the prevalence of the virus in some oil rich communities of Niger Delta. Nevertheless, it is therefore strongly expected that the epidemiological data generated from this study, would succinctly redirect government policies towards an effective management strategy of this social scourge, especially among the weak and poor in the remote villages where access to functional health care facilities and availability of the antiretroviral drugs remains a massive critical challenge to handle [13].

\section{Methodology}

\section{Sample area}

Subjects for this study were drawn from seven (7) locations within Ahoada East Local Government Area of Rivers State located in the Niger Delta region of Nigeria. This area is one of the 23 Local government areas in the state and is made up of predominantly farmers, fishermen and traders. A few are civil servants who also indulge in subsistence farming. It is surrounded by Omoku, Rumuekpe, Ahoada West, Obagi, Elele, Obricom and Erema communities which are host communities to oil exploration and as such has a large presence of persons seeking for greener pastures in the oil and gas sector. The locations used include the Community Health Center Edeogha-Ekpeye (Location 1), Community Health center Ochigba (Location 2), Comprehensive Health Center Ahoada (Location 3) and Ahoada General hospital (Location 7). Samples were also collected from three (3) communities which are non-hospital/clinic based collection centers namely Ula-upata (Location 4), Ahoada Timber Market (Location 5) and Ogbo town (Location 6). The age of the subjects were $\geq 15$ and included both males and females (Figure 1).

\section{Sample collection/Experimental}

Blood samples of the subjects were collected using sterile $2 \mathrm{ml}$ syringe, immediately transferred to a serum bottle and allowed to clot. The collected samples were centrifuged at $2000 \mathrm{rpm}$ for 5 minutes and sera recovered and stored at $-20^{\circ} \mathrm{C}$ till they were needed. Screening for HIV1 and 2 was done using a double Enzyme-Linked Immunosorbent Assay (ELISA) method made up the Determine (Abbott Laboratories, Japan), and Stat-Pak HIV1 and 2 kits (Chembio Diagnostics, USA). The Determine HIV 1 and 2 kits are used in vitro to qualitatively detect HIV type 1 and 2 antibodies in human serum while the Stat-Pak HIV1 and 2 kits is often used as a confirmatory test for the HIV. The Stat-Pak kit is based on immune chromatography and involves the combination of a specific antibody binding protein joined to a colloidal gold dye particle and HIV1 and 2 antigens bound to the membrane phase which is solid. In this study, all sero-positive samples were re-screened for the Subtype (1 and 2) using the SD Bioline HIV1 and 2 kit (Standard Diagnostics, Korea). The screening process was however done according to manufacturers' instructions. Results were presented using charts.

\section{Data Analysis}

The data obtained were analyzed using Microsoft Excel package 2010, and results were presented in charts with error bars as shown below. 
Citation: Obioma A, Chikanka AT (2018) Influence of Confounding Evidence Based Risk Factors Triggering the Incidence of HIV Antibodies among Screened Population of Niger Delta Extraction. Insights Biomed Res 2(1):32-39

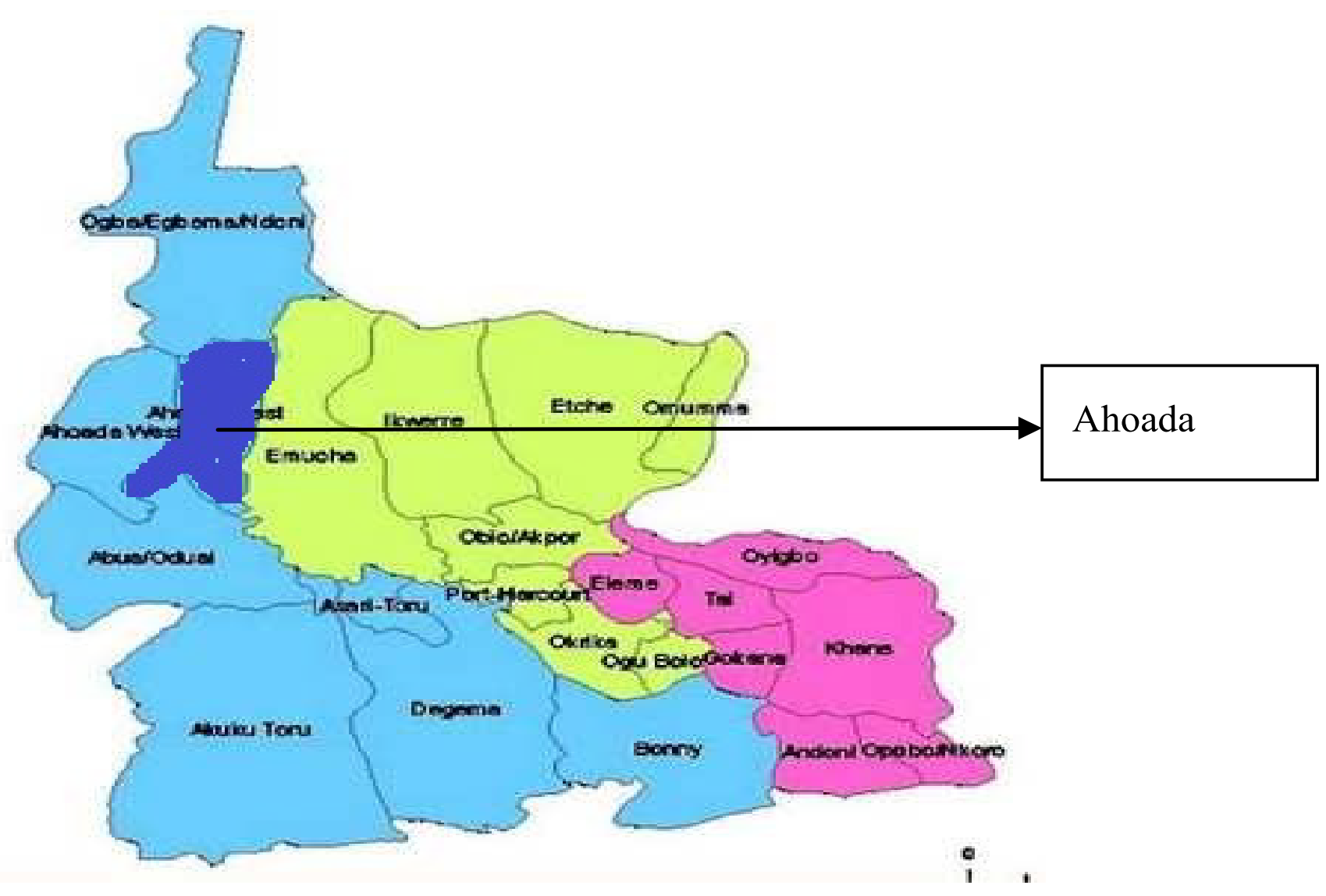

Figure 1: Map of Rivers State (Blue spot indicates the study location).

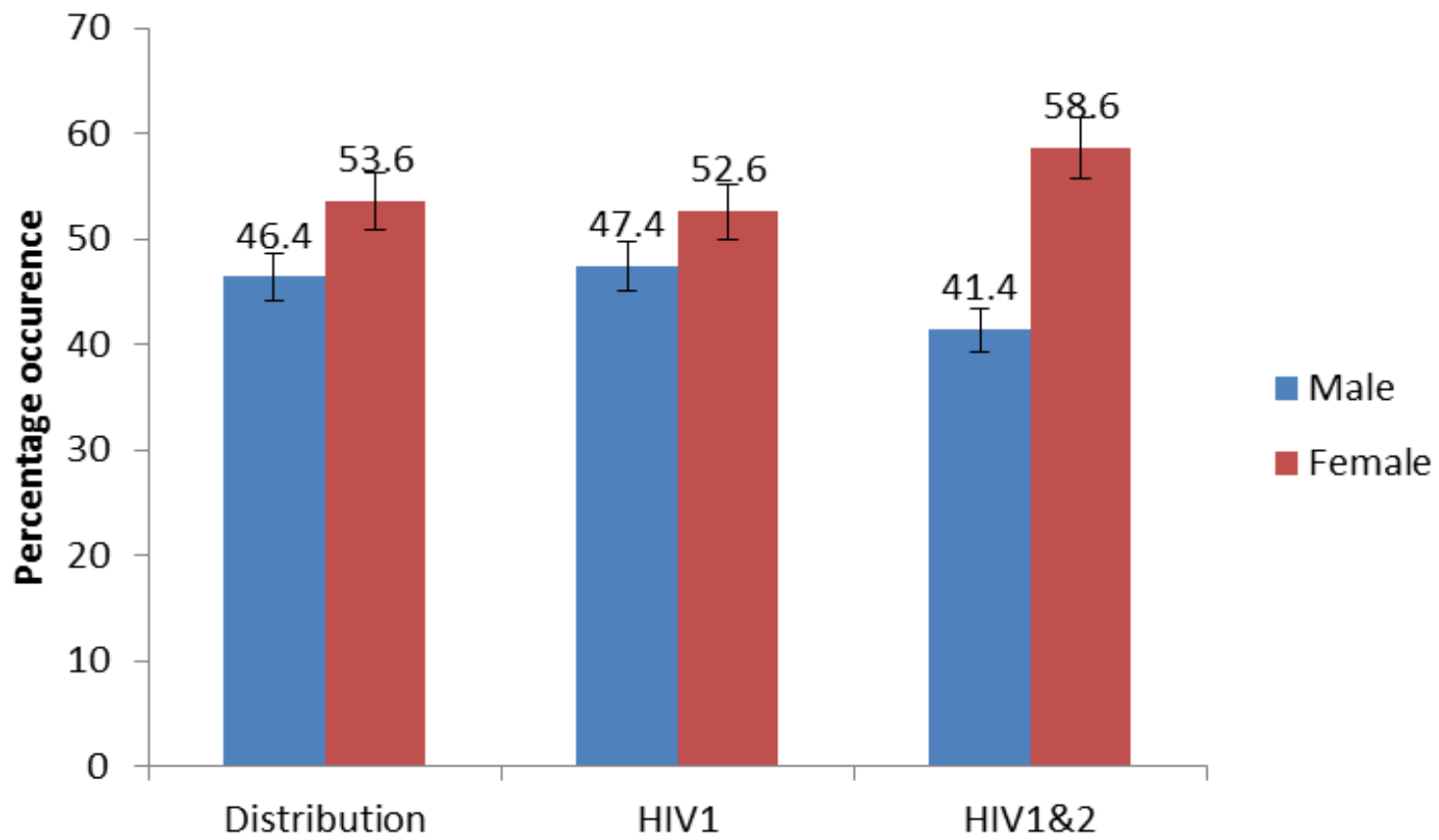

Figure 2: Percentage prevalence of HIV1 and HIV1 and 2 among males and females.

\section{Resullits}

Analysis of HIV1 and HIV1 and 2 seropositive persons in randomly selected 1000 respondents in Ahoada East Local Government Area of River State recorded a
$10.7 \%$ prevalence rate as 107 persons tested positive to the HIV antibody. Of these, $7.8 \%$ were HIV1 positive while $2.9 \%$ were HIV1 and 2 positive. Females made up $53.6 \%$ of the study population while males made up 
Citation: Obioma A, Chikanka AT (2018) Influence of Confounding Evidence Based Risk Factors Triggering the Incidence of HIV Antibodies among Screened Population of Niger Delta Extraction. Insights Biomed Res 2(1):32-39

46.4\%. 47.4\% and 52.6\% were HIV1 positive among the males and females respectively while $41.4 \%$ and $58.6 \%$ were both HIV1 and 2 positive among the males and females respectively as seen in Figure 2. Persons within ages 25-34 had the highest prevalence for HIV1 (44.9\%); 15-24 had 34.6\%, 35-44 had 20.5 and 45-54 had none. Ages 45-54 had the highest prevalence of HIV1 and 2 cases (51.7\%) while ages 15-24 and 25-34 had none as seen in Figure 3. Farmers made up a higher percentage of those with HIV1 and 2 while students made up a higher percentage of those with HIV1 as presented in Figure 4. Those with only First School Leaving Certificate (FSLC) constituted a major part of those with HIV1 while those with the Senior School Certificate (SSCE) made up a huge part of those with HIV1 and 2 as seen in Figure 5. Singles made up $67.9 \%$ of those who were HIV 1 positive while married persons made up $55.2 \%$ of those positive for HIV 1 and 2 as seen in Figure 6. Figure 7 shows that majority of the positive subjects admitted to knowing that condoms could help prevent the transmission of HIV. Location 7 had the highest percentage occurrence of both HIV1 and HIV1 and 2 as seen in Figure 8.

\section{Discussion}

The study was carried out among indigenes of Ahoada East Local Government Area of Rivers State and recorded

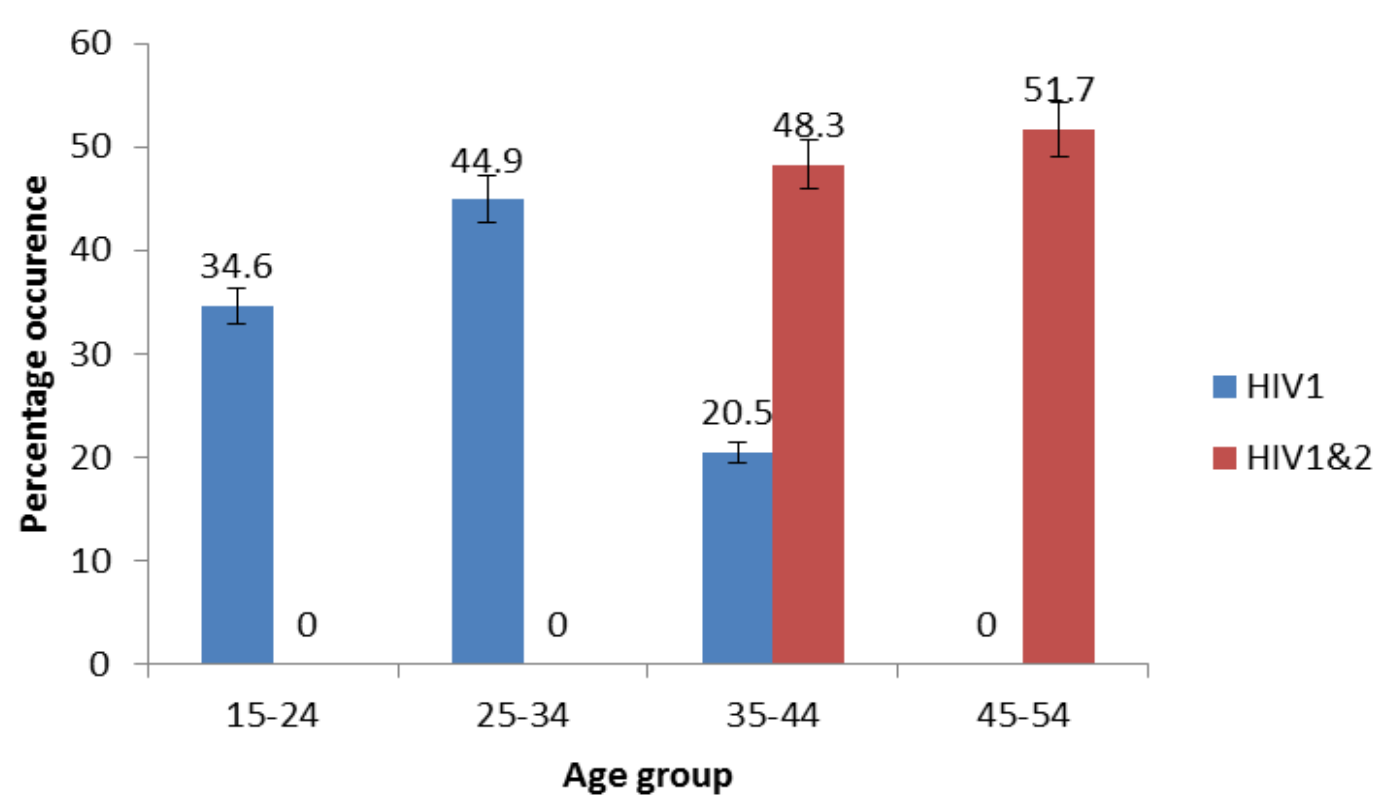

Figure 3: Percentage prevalence of HIV1 and HIV1 and 2 among different age groups.

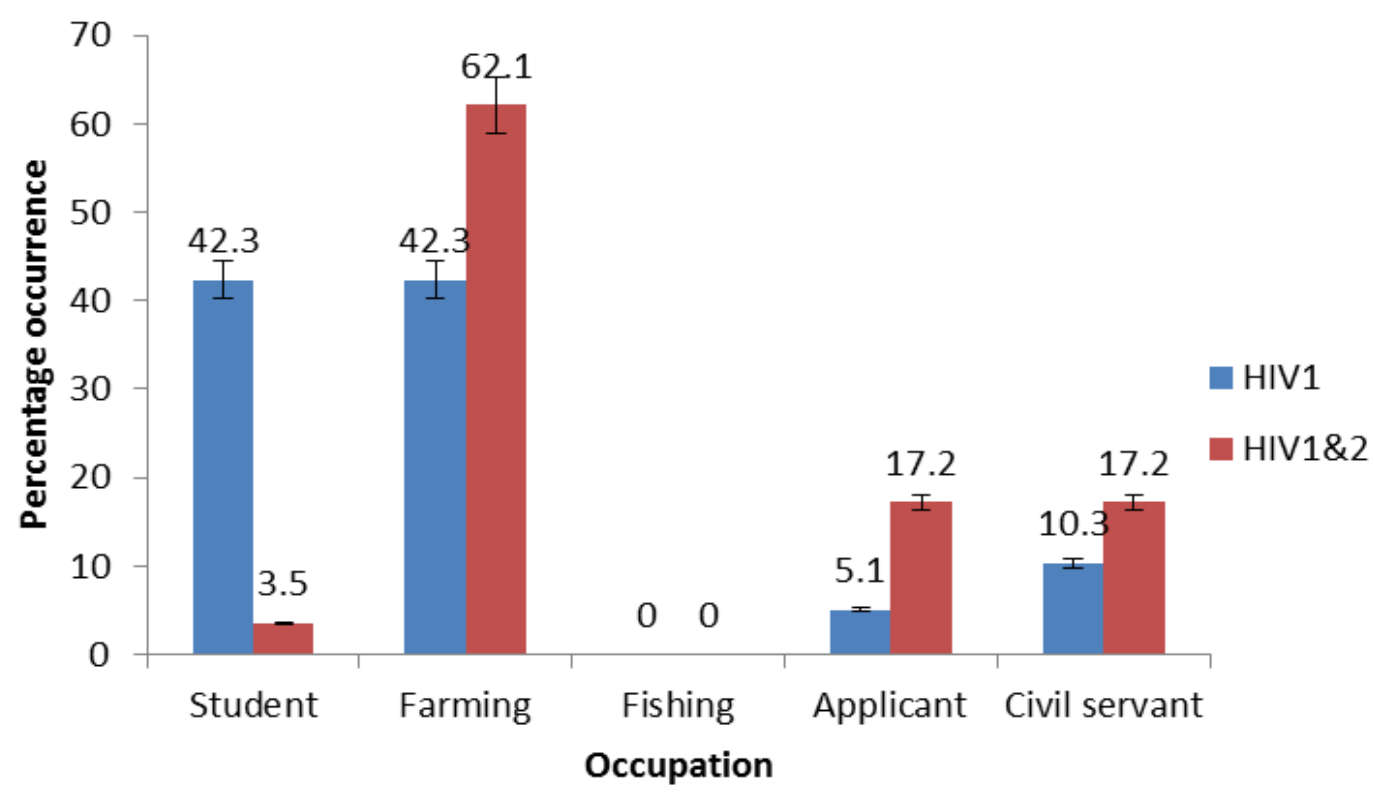

Figure 4: Percentage prevalence of HIV1 and HIV1 and 2 based on occupation. 
Citation: Obioma A, Chikanka AT (2018) Influence of Confounding Evidence Based Risk Factors Triggering the Incidence of HIV Antibodies among Screened Population of Niger Delta Extraction. Insights Biomed Res 2(1):32-39

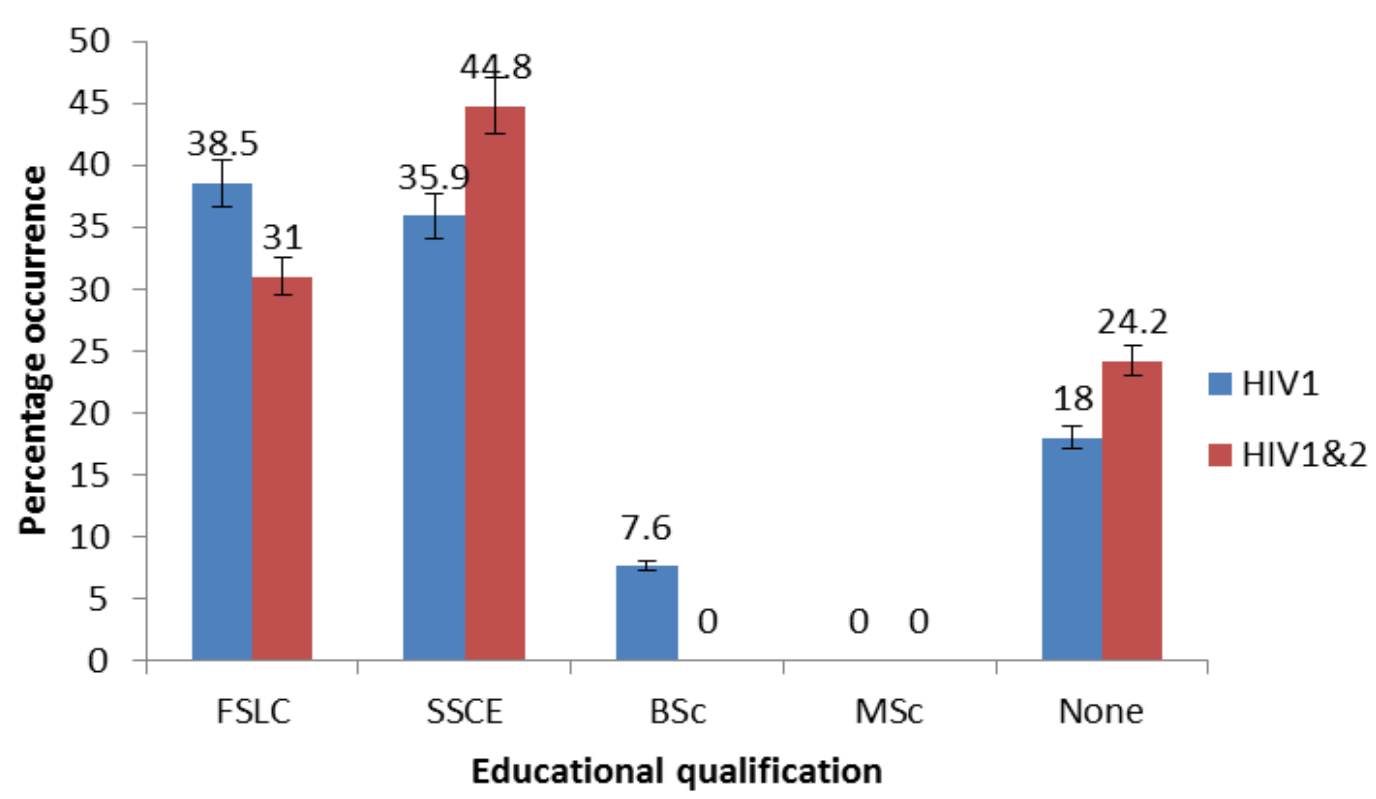

Figure 5: Percentage prevalence of HIV1 and HIV1 and 2 based on educational qualification.

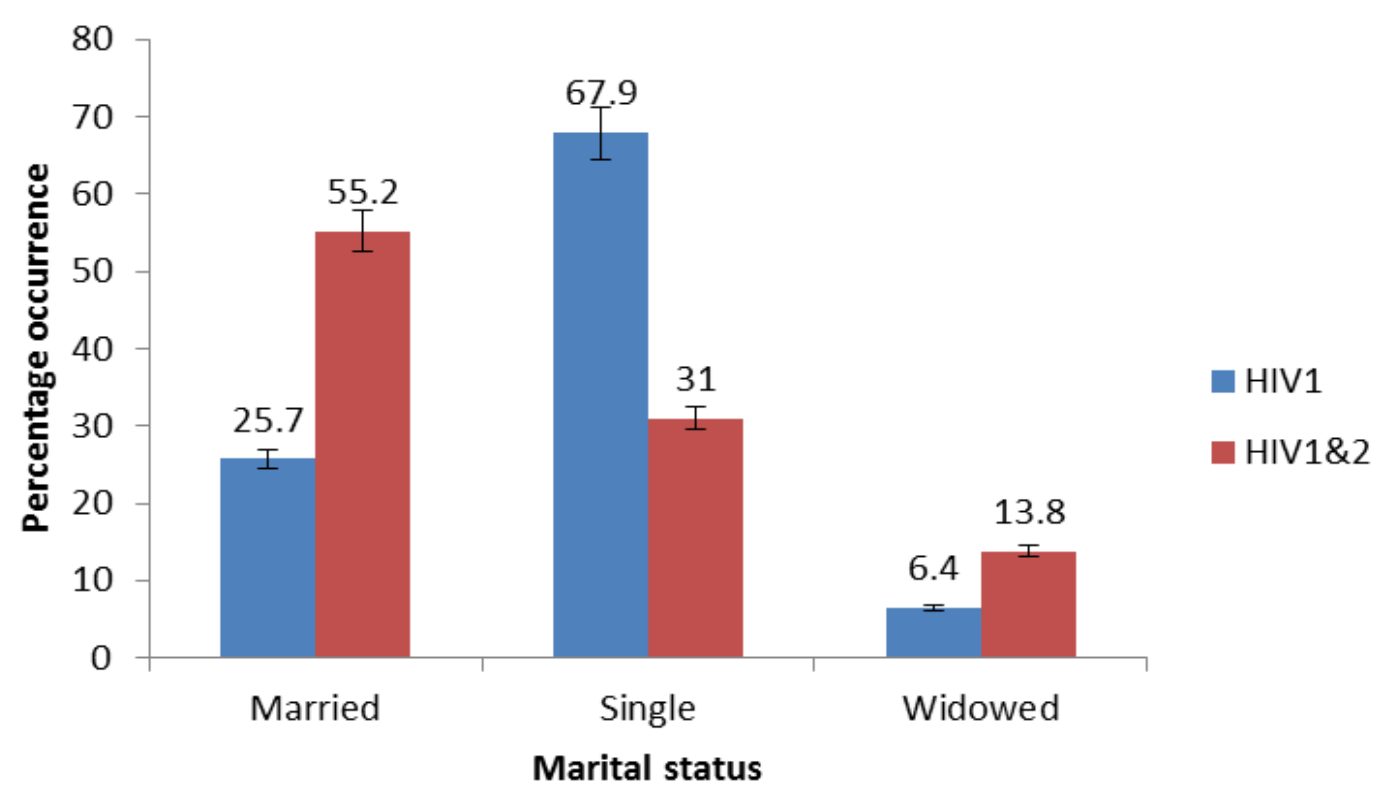

Figure 6: Percentage prevalence of HIV1 and HIV1 and 2 based on marital status.

a total prevalence of $10.7 \%$. Females accounted for $52.6 \%$ and $58.6 \%$ of the total HIV 1 and 2 prevalence, respectively. This increase in prevalence in females has been reported by Azuonwu, et al. [14], NACA [15] and Azuonwu, et al. [13]. Also, in another study carried out by Akinjogunla and Adegoke [16] in Uyo, Nigeria, they recorded a higher prevalence among females compared with that of males. This increase in female prevalence has been linked to poverty, harmful traditional rites, political and legal factors, girl child marriage, disabilities and gender-based violence [15]. Also, according to Azuonwu, et al. [13], sexual promiscuity, rape and prostitution are some risk factors that may have led to the increased prevalence among females. The possibility of them contacting the disease from needles and blades used on their hair and nails from the saloon, manicure and pedicure shops is not inevitable, as safety and personal hygiene policies of the study location remains weak till date. From the results also, HIV 1 and 2 prevalence was higher than that of HIV 1 which means there was a co-infection and these persons may have contacted both serotypes from two sources without prior knowledge. Okerentugba, et al. [17], however recorded a prevalence of $67 \%$ and $33 \%$ for HIV 1 and 2 serotypes respectively among pregnant women in a hospital in Port Harcourt.

The prevalence among the different age groups differed even based on the serotypes. Ages 25-34 had a higher 
Citation: Obioma A, Chikanka AT (2018) Influence of Confounding Evidence Based Risk Factors Triggering the Incidence of HIV Antibodies among Screened Population of Niger Delta Extraction. Insights Biomed Res 2(1):32-39

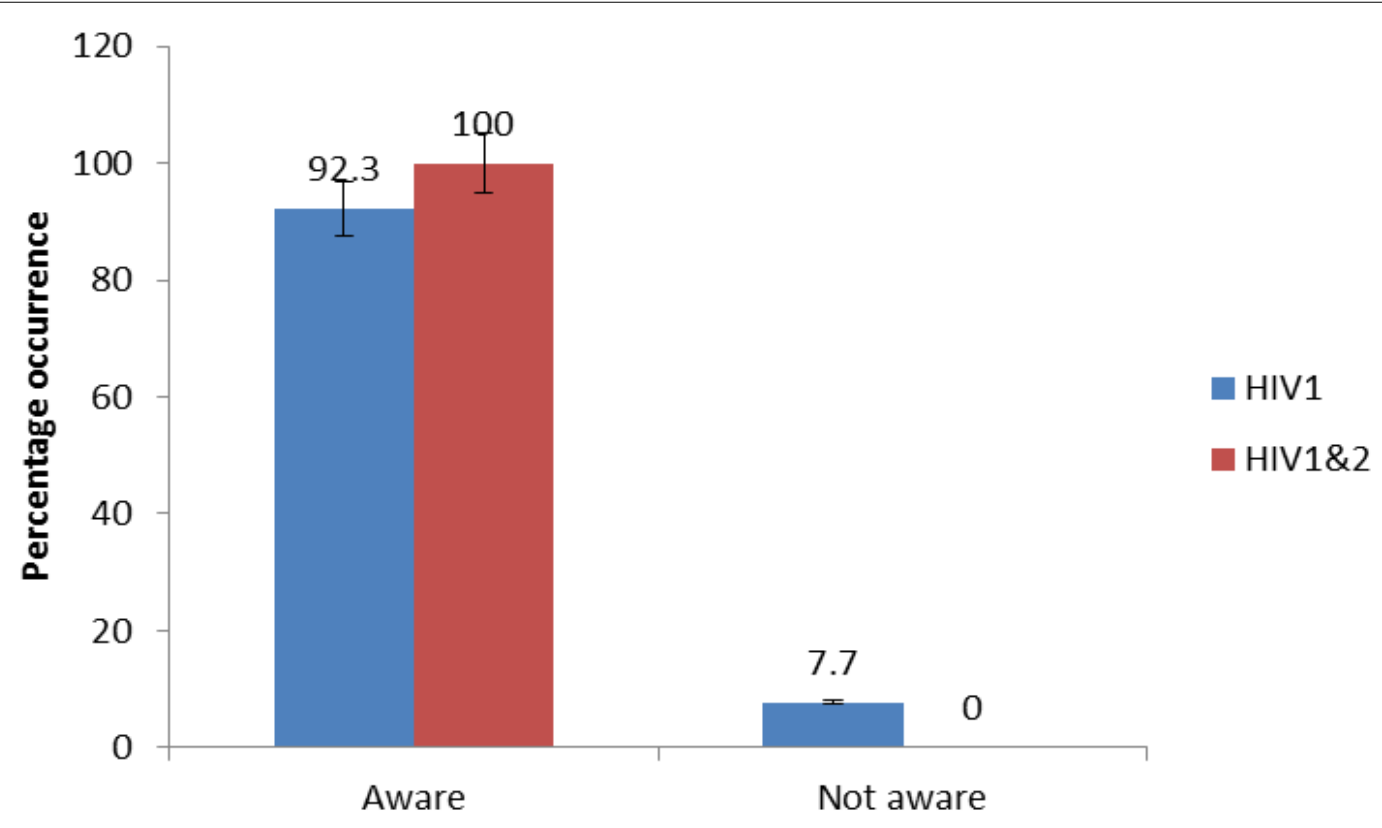

Figure 7: Awareness of HIV positive persons on the use of condoms as preventive measure.

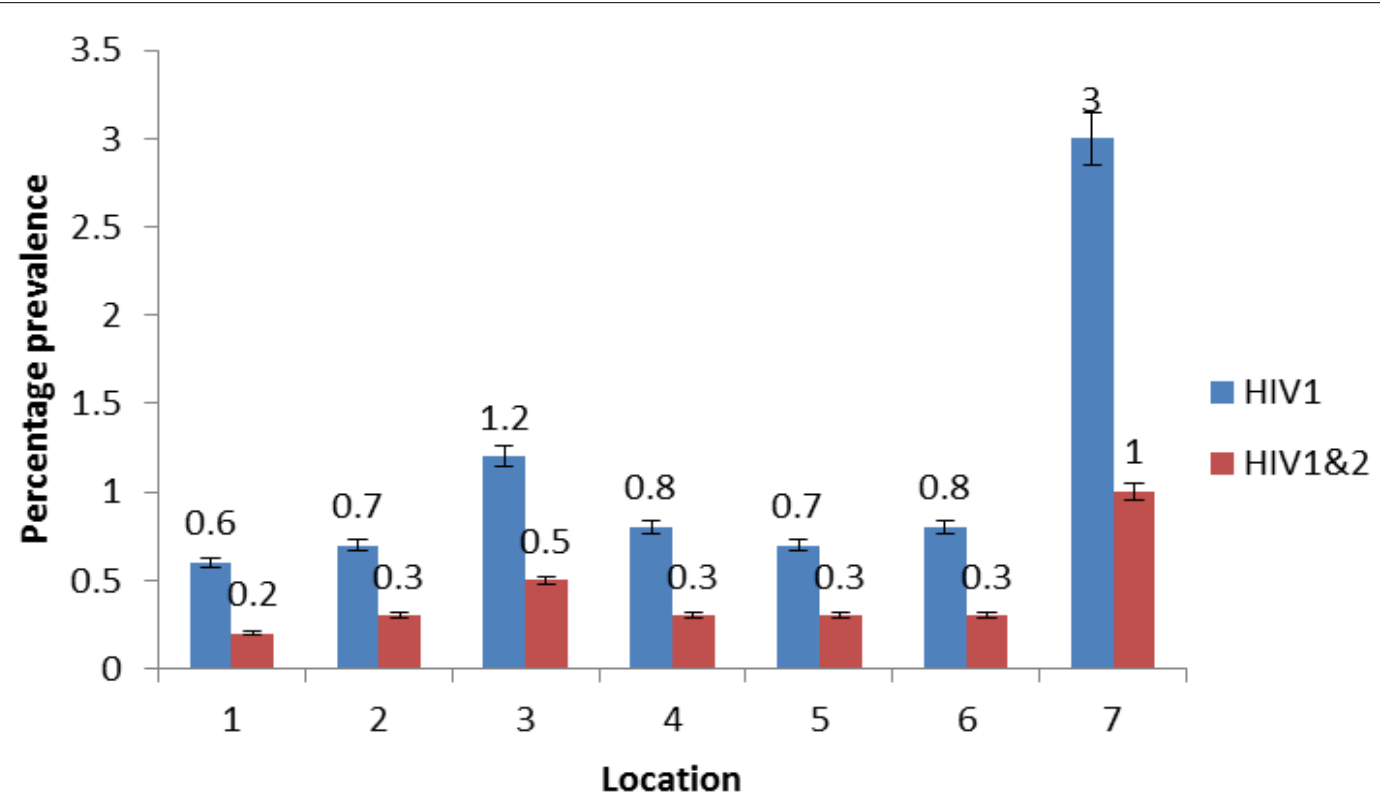

Figure 8: Percentage distribution of HIV1 and HIV1 and 2 prevalence in the seven locations.

HIV 1 (44.9\%) while ages 45-54 had a higher HIV 2 prevalence $(51.7 \%)$. Although there is paucity of prevalence of the different HIV serotypes based on age, ages 25-34 are usually implicated in high HIV prevalence. Azuonwu, et al. [13] recorded a higher HIV prevalence among persons between ages 22-28 in a study carried out in a Niger Delta community. Also, in another study carried out in a community in Rivers State, persons within ages $21-26$ had the highest prevalence [14]. Idleness is also a factor as most youths who do not have jobs fall back to risky activities such as intravenous drug use as well as they may be victim of rape when they are probably under the influence of hard drugs. More often, this age group is seen as the age when there is high sexual demand and also sharing of sharp objects such as needles, blades and clippers which are all risk factors for HIV transmission.

Nonetheless, farmers recorded a higher HIV 1 and 2 prevalence $(62.1 \%)$ while students and farmers recorded same HIV 1 prevalence (42.3\%). The distance of the farms from dwelling places may have probably provided a room for the farmers to be involved in sexual promiscuity, as well as increase the incidence of rape. Students may have involved themselves in after school or even within school hour's activities such as intravenous drug use and illicit sex behaviors. The desire to be like their peers who have been involved in these may have driven them to be involved in these activities. 
Citation: Obioma A, Chikanka AT (2018) Influence of Confounding Evidence Based Risk Factors Triggering the Incidence of HIV Antibodies among Screened Population of Niger Delta Extraction. Insights Biomed Res 2(1):32-39

More often, singles out of desperation and financial benefits also get involved in activities that predispose them to HIV. These may have been responsible for the increased HIV 1 prevalence in singles than the other two groups. Some persons even when married may be unfaithful to their spouses and end up being sexually promiscuous. On the other hand, these persons whether married, single or widowed may have been exposed to this virus because of the nature of their job (e.g. health personnel) especially in a weak health system that lack personal protective equipment and absolute barrier nursing is not practice to enhance the safety of staff.

It is worthy of note that persons with the highest educational qualification in this study (MSc) recorded no prevalence while those with BSc recorded the least prevalence of $7.6 \%$. The highest prevalence was recorded among those with the Senior School Certificate (SSCE). Education within the four walls of a university may have thus played a huge role in reducing the occurrence of HIV among them. More often, they have knowledge of the use of condoms as a means of preventing the spread of HIV. On the other hand, persons with no education had a lower prevalence than those with FSLC and SSCE. This may be attributed to home training as in most homes, informal education is carried out and members of the home are advised to keep off from immoral behaviors. Location 7 accounted for a major percentage of the total prevalence of both HIV 1 and HIV 1 and 2 co-infection. This location is the Ahoada General Hospital and is usually busy as most persons visit the hospital often with complicated illnesses, thus this may probably be the reason for an increased prevalence rate.

The awareness on the use of condoms for the prevention of the HIV was very high as majority of the subjects admitted to knowing that condoms could prevent the spread of the virus. The issue is however not in knowledge but in the practice of that which is known. One could however say if a good number of the subjects knew condoms could prevent the spread of the virus and yet they contacted the virus; They may have contacted it through other means such as the sharing of sharp objects, rape or mother to child transmission.

\section{Conclusion}

In this study carried out, the HIV prevalence was $10.7 \%$ with $2.9 \%$ testing positive to both HIV 1 and 2 and $7.8 \%$ testing positive to HIV 1 and 2. Majority of the HIV positive subjects were HIV 1 and 2 positive. Some of the reasons pointed at for the presence of this virus were sexual promiscuity, sharing of sharp objects, child marriage, rape, heterosexuality, homosexuality, poverty, violence on a particular gender, disabilities and traditional rites that are harmful especially to females.

\section{Recommendation}

Continuous and frequent surveillance should be carried out especially in rural areas where little or no attention is given to individual's health outcome. Individuals should be encouraged to visit a health facility to know their HIV status whether or not they feel ill as the virus may be latent and asymptomatic for a long period of time. Employment opportunities should be provided so as to prevent youths from indulging in illicit activities due to idleness.

\section{Acknowledgment}

We are sincerely grateful to all the subjects who willingly participated in the study. We are also thankful to Dr Azuonwu, Goodluck, Dr (Mrs) G, N Wokem and all the laboratory staff where the assay was done for all their technical support.

\section{Conflict of Interest}

None noticed among authors.

\section{References}

1. Nasidi A, Harry TO (2006) The epidemiology of HIVIAIDS in Nigeria. In: Adeyi O, Kanki PJ, Odutolu O, Idoko JA, AIDS in Nigeria: A nation on the threshold. Harvard center for population and development studies, Cambridge.

2. Eze JI (2009) Modeling hiv/aids epidemic in nigeria (Ph.D. thesis). University of Glasgow.

3. World health organization fact sheet (2014) Global update on the health sector response to hiv, geneva. Joint United Nations Programme on HIV and AIDS.

4. United states agency international development. Orphans and vulnerable children affected by hiv and aids.

5. Federal ministry of health (2013) National hiv \& aids and reproductive health survey 2012, NARHS Plus II.

6. United States Agency International Development (2013) Hiv/aids health profile: Sub-Saharan Africa.

7. National Agency for the Control of Aids (2012) Global aids response: Country progress report. Garpr, Abuja, Nigeria.

8. National Agency for the Control of Aids (2014) Global aids response: Country progress report, Nigeria.

9. National Agency for The Control of Aids (2010) United Nations general assembly special session (ungass) Country progress report. Nigeria.

10. Azuonwu O, Erhabor O, Obire O (2012) HIV among military personnel in the Niger delta of Nigeria. J Comm Health 37: 25-31.

11. UNICEF Information Sheet (2007) HIVIAIDS. UNICEF, Nigeria.

12. Awofala AA, Ogundele O (2016) HIV epidemiology in Nigeria. Saudi Journal of Biological Sciences 25: 697-703.

13. Azuonwu O, Azuonwu TC, Akpelu G (2017) Evaluation of cofounding hiv sero-prevalence and associated risk factors among subjects in some upland communities of Niger delta, Nigeria. Int J Pub Health Safe 2: 137. 
Citation: Obioma A, Chikanka AT (2018) Influence of Confounding Evidence Based Risk Factors Triggering the Incidence of HIV Antibodies among Screened Population of Niger Delta Extraction. Insights Biomed Res 2(1):32-39

14. Azuonwu O, Ihua A, Wokem GH, et al. (2017) Prevalence of human immunodeficiency virus (HIV) antibody among subjects in ogba/egbema/ndoni local government area (LGA) of Rivers State of Nigeria. Translational Biomedicine 8: 118.

15. National Agency for the Control of Aids (2015) Global aids response Country progress report, Nigeria.
16. Akinjogunla OJ, Adegoke AA (2009) Sero-prevalence of human immunodeficiency virus (hiv) 1 and 2 infections in uyo metropolis, Akwa Ibom State. SRE 4: 590-593.

17. Okerentugba PO, Uchendu SC, Okonko IO (2015) Prevalence of hiv among pregnant women in rumubiakani, port harcourt, Nigeria. Public Health Research 5: 58-65. 